\title{
Transborder Ethnic Kin and Civil War
}

\author{
Lars-Erik Cederman, Kristian Skrede \\ Gleditsch, Idean Salehyan, and \\ Julian Wucherpfennig
}

\begin{abstract}
A series of studies has shown that civil wars are caused not only by factors inside countries, but also by effects operating across state borders. Whereas a first wave of quantitative studies demonstrated that such effects make the "closedpolity" assumption untenable, more recently researchers have identified particular causal mechanisms driving conflict. Despite these recent advances, a central puzzle remains unresolved, namely why ethnic groups that at least in theory could count on support from large transborder ethnic kin (TEK) groups often have remained surprisingly peaceful, such as the stranded Russian populations in the "near abroad." We propose a theoretical framework that extends the analysis from the primary dyad between the incumbent and the challenger group by adding a secondary dyad that pits the incumbent against the TEK group. We postulate a curvilinear effect of the TEK group's relative size on conflict onset. Using a new data set on transnational ethnic links, we find that that the risk of conflict increases within the middle range of the size spectrum, consistent with our main hypothesis. This means that large TEK groups have a conflict-dampening effect, provided that they control their own state. Excluded TEK groups, however, are not associated with lower conflict probabilities.
\end{abstract}

Beyond the clear importance of domestic opportunities and grievances, civil wars are often influenced by the wider international environment. A series of recent stud-

An earlier version of this research note was presented at the annual meeting of the American Political Science Association, Seattle, 2 September 2011. We are grateful for the helpful comments by Stephen E. Gent and the editors and anonymous referees of this journal. Arman Grigorian and Andreas Wimmer offered important conceptual input at the initial stage of this project. We are also grateful to Seraina Rüegger for coordinating the collection of the TEK data, which builds on her coding efforts and that of several other coders, including Nils-Christian Bormann, Manuel Vogt, Michael Bürge, Omar Kassab, and Charlotte Fidler. Additionally, Philipp Hunziker provided excellent assistance with calculations of the key variables and data management. Cederman and Salehyan acknowledge financial support from the Swiss Network of International Studies (SNIS). Gleditsch acknowledges support from the Research Council of Norway (1804410/V10). The online appendix is available at www.journals. cambridge.org/ino2013005.

Note from the editors: This article was accepted for publication before one of its authors became an associate editor of this journal.

International Organization 67, Spring 2013, pp. 389-410

(C) 2013 by The IO Foundation.

doi:10.1017/S0020818313000064 
ies has shown that such violence is caused not only by factors inside countries, but also by effects operating across state borders. ${ }^{1}$ Whereas a first wave of quantitative studies demonstrated that such effects make the "closed-polity" assumption untenable, more recently researchers have identified particular causal mechanisms driving conflict, including the role of transborder ethnic kin (TEK) in conflict processes. In contrast to earlier contributions to this literature, which tended to stress identity as the key motivating factor, contemporary scholarship typically highlights how the conjunction of ethnicity and power politics increases the risk of conflict, suggesting that "identity politics is often more about politics than about identity." 2

Despite these recent advances, a central puzzle remains unresolved, namely how ethnic groups that at least in theory could count on support from large TEK groups often have remained surprisingly peaceful. The most prominent dog that failed to bark in this sense are the Russians in the "near abroad." There was widespread anticipation that the Russian diasporas stranded in former Soviet republics after the collapse of the Soviet Union in the early 1990s would resort to violence, but these communities have remained relatively calm. However, the picture looks entirely different if we consider the Albanians in the former Yugoslavia, or the Armenians in Azerbaijan. These groups have been involved in major fighting with active support from TEK groups. Given a similar pattern of domestic marginalization and cross-border ethnic kin, why then do some groups rebel while others do not?

We seek to ascertain whether there is any systematic link between the transnational ethno-demographic balance and the probability of conflict. We conjecture that the effect is not linear: as the size and power of TEK groups rise, conflict should be more likely, but very strong kin groups-such as the Russians-can in fact deter conflict. Our argument has been anticipated by others. In an article on "hypotheses on nationalism and war" that appeared shortly after the end of the Cold War, Van Evera proposed the existence of such a curvilinear effect. ${ }^{3}$ Offering a more thorough theoretical derivation, Van Houten addressed the same puzzle, arguing that large external states controlled by TEK groups could have a pacifying effect on ethnic politics. ${ }^{4}$ Yet the author also admits that his study should be seen as a plausibility probe rather than a definitive test, since the evidence is limited to selected case studies. Thus, almost two decades after the publication of Van Evera's initial conjecture, it remains uncertain if the postulated conflictreducing TEK effect holds.

We test whether the curvilinear proposition applies more generally. Progress in data collection now allows us to evaluate this proposition systematically across a large number of cases. Drawing on a new transnational extension to the Ethnic

1. See Salehyan and Gleditsch 2006; and Gleditsch 2007.

2. See King and Melvin 1999/2000, 109; Thyne 2006; and Cederman, Girardin, and Gleditsch 2009.

3. Van Evera 1994.

4. Van Houten 1998. 
Power Relations (EPR) data set, we find strong quantitative support for the hypothesis. Indeed, the propensity of conflict is highest for TEK groups with intermediate relative sizes. As "power parity" theories would expect, external groups that have approximately the same size as the incumbent groups tend to see the most conflict. However, there are important differences regarding the TEK group's power status. Contrary to common fears about the dangers of irredentism, our results show that if transnational communities happen to control their respective states, this influence has a conflict-dampening impact for large groups. Where the TEK group is stateless, however, one cannot count on such a reduction of conflict risk.

\section{The Literature on Transborder Ethnic Kin and Conflict}

There is little consensus in the literature on how TEK influence civil war outbreak. In fact, virtually all conceivable causal relationships have been proposed at some point or another, including both positive and negative influences, as well as no connection at all. Some studies argue that TEK groups have offensive motives linked to ethnic nationalism and postulate a positive effect on conflict. In particular, aggressive interventions driven by irredentism could trigger a spiral of escalating tensions on both sides of the border. ${ }^{5}$ It is not difficult to find examples of such border-transgressing processes in the wars that led to the breakup of the former Yugoslavia. Although most of this literature relies on qualitative evidence, ${ }^{6}$ some scholars have conducted quantitative tests, usually based on Minorities at Risk (MAR) data, that generally detect a positive impact on conflict exerted by TEK groups. ${ }^{7}$

From the vantage point of bargaining theory, Cetinyan contends that group sizes and transnational kin groups should not influence the probability of conflict onset. ${ }^{8}$ This interpretation recognizes that demands vary with a group's demographic weight, but rejects any implications for the outbreak of violence. Potential threats from external kin, Cetinyan argues, should be reflected in domestic bargaining processes as groups with strong TEK ties receive greater concessions from the state. Cetinyan's analysis is creative, but there are at least two reasons to doubt his theoretical and empirical null effect. First, the restricted sample of groups in the MAR data, which are by construction limited to threatened minorities, make them less suitable for general tests of demographic size. Second, Cetinyan's model rules out the possibility that relative group size could be correlated with uncertainty. By contrast, a number of scholars postulate a curvilinear relationship between the two,

5. Weiner 1971.

6. See, for example, Jenne 2007; Horowitz 1985; Chazan 1991; and Heraclides 1990.

7. See Davis and Moore 1997; Saideman 2001; and Woodwell 2004.

8. Cetinyan 2002. 
since strategic misrepresentation is most effective at parity. ${ }^{9}$ We present a similar argument. In fact, the conflict literature has also postulated similar nonlinear effects, such as the influence of regime type ${ }^{10}$ and ethnic fractionalization. ${ }^{11}$

In an attempt to overcome some of the sample restrictions associated with the MAR data by relying on alternative, group-level data, Cederman, Girardin, and Gleditsch find that TEK groups increase the probability of internal conflict by shifting the shape of the observed effects of the power balance between the groups associated with the rebels and the incumbent government. ${ }^{12}$ While innovative in its use of geographic information systems, their article has a limited scope. First, the data on ethnic groups depend directly on the Soviet Atlas Narodov Mira, ${ }^{13}$ which are defined primarily based on language, and may not correspond to the relevant identities. ${ }^{14}$ Moreover, the data are from the 1960s and could thus be outdated (even though ethnic settlement patterns are surprisingly stable over time). Second, their analysis is limited to Eurasia, thus leaving cases in Africa and the Western Hemisphere outside the analysis. Third, and most importantly, their model does not factor in the size of the TEK group itself, and therefore does not speak to the size puzzle.

In an early discussion of "hypotheses on nationalism and war" mentioned earlier, Van Evera develops a subtle argument stating that TEK groups will be less likely to intervene if rescue is either impossible or relatively easy. It is, instead, "inbetween situations ... that are most dangerous." 15 However, Van Evera's article never moves beyond listing hypotheses accompanied by selected case illustrations.

Relatedly, Van Houten offers a more sophisticated attempt to explain the relative peacefulness of the Russian near abroad and similar cases. ${ }^{16}$ Focusing on kin states, referred to as "reference states," Van Houten extends Fearon's theory of credible commitments from minority-majority relations to transborder actors. ${ }^{17}$ Noting that Fearon's argument overpredicts violence in cases such as the Baltic states, he argues that external relations may pacify domestic settings under specific conditions. It is true that irredentist intensions may exist among strong states in which case conflict is very likely. However, ceteris paribus, a stronger reference state should stabilize minority-majority relations: "the presence of a militarily strong but only moderately irredentist reference state is most likely to overcome the commitment problem and prevent ethnic violence." ${ }^{18}$ Thus, strong external kin states are in a much better position to make credible threats to intervene than their weaker counterparts:

9. See, for example, Walter 2009; and Reiter 2003.

10. Hegre et al. 2001.

11. Sambanis 2001.

12. Cederman, Girardin, and Gleditsch 2009.

13. Bruk and Apenchenko 1964.

14. Ibid. The geocoded groups are introduced in Weidmann, Rød, and Cederman 2010.

15. Van Evera 1994, 20.

16. Van Houten 1998.

17. Fearon 1998.

18. Van Houten 1998, 119-20. 
On the one hand, if it is known that the reference state is likely to intervene in the new state if the minority is oppressed, then the ruling majority in the new state has an incentive to protect the minority. This threat allows the majority to credibly commit to do this. On the other hand, if the reference state is too aggressive, it may induce a war with the new state. ${ }^{19}$

Recognizing the difficulties of testing an argument that hinges on intensions, Van Houten limits the application of his game-theoretic model to a small number of cases in Eastern Europe: "I make no attempt to actually prove the correctness of the model; rather, I try to show its plausibility." ${ }^{20}$ Thus, building on and further developing Van Houten's ideas, we attempt to go beyond establishing plausibility by testing our hypotheses systematically across a large number of cases.

\section{Theorizing the Effect of Transborder Ethnic Kin}

Following pioneering conceptual work by Weiner ${ }^{21}$ and Brubaker, ${ }^{22}$ we start our theoretical derivation of the TEK effect by identifying the ethno-nationalist triad as the critical constellation of actors within which border-transgressing influences on conflict operate. An ethno-nationalist triad can be conceptualized as an extended center-periphery configuration by adding the TEK group to the primary dyad, which involves the group challenging the power of an incumbent ethnic group. Through the addition of a TEK group on the challenger's side, the incumbent is now faced with an additional potentially opposed actor in a secondary dyad. The presumably supportive relationship between the TEK group and the challenger constitutes the third leg of the triad. Figure 1 illustrates the full triadic actor constellation, including the primary and secondary dyads.

By referring to incumbents, challengers, and TEK groups, we avoid the confusing and potentially misleading terminology labeling the first two actors as majority and minority groups. Rather, we highlight the importance of the ethno-political power. As illustrated by many cases of minority rule, including apartheid South Africa and modern-day Syria, the incumbent group at the political center may be a numerical minority and the excluded challenger group(s) in majority. Such situations are especially conflict prone.

Although our theoretical framework could in principle be extended beyond neighboring states, we focus on such relations for the simple reason that external intervention is much more feasible in terms of logistics under such circumstances. Indeed, long-distance nationalism involving diaspora has also been listed as a pos-

19. Ibid.

20. Ibid., 119-20 (emphasis in original).

21. Weiner 1971.

22. Brubaker 1996. 
sible source of conflict, ${ }^{23}$ as has funding of rebel campaigns in the developing world through diaspora of migrants in the United States. ${ }^{24}$ These conflict mechanisms are different from our concern, since we focus entirely on transborder ethnic kin. It is true that demonstration effects may inspire protest across vast distances. However, few countries have the ability to project force across long distances, and such kin group connections are less relevant for threat perceptions. Moreover, TEK groups in adjacent countries can more readily offer support to their kin across the border, for example, by helping to set up rebel sanctuaries. ${ }^{25}$

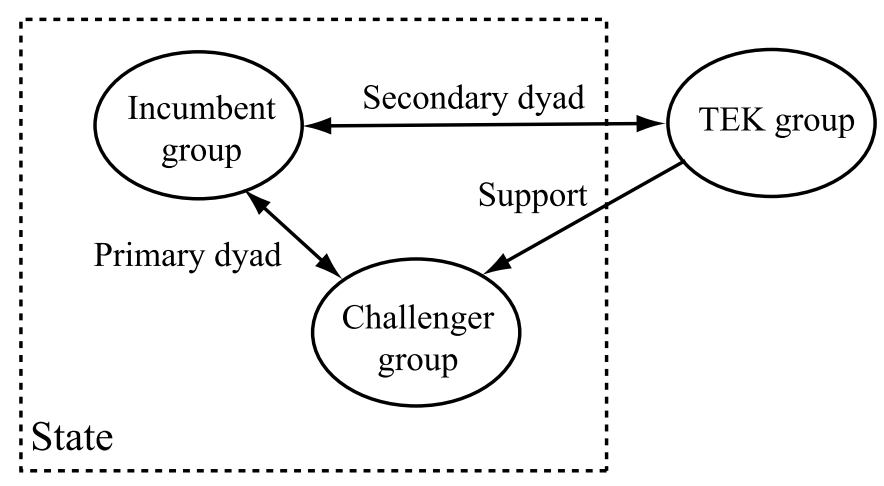

FIGURE 1. The ethno-nationalist triad

Although our actor constellation is based on ethnic groups and focuses on mechanisms governed by demographic conditions, the agency of ethnic groups as collective actors has often been questioned in the literature. In the classical treatment of collective action, Olson expects free riding to undermine the effectiveness of large groups' efforts. ${ }^{26}$ More recently, experts on conflict and ethnicity have criticized the reliance on ethnic groups as the unit of analysis. ${ }^{27}$ For sure, many ostensible groups may not live up to the full "groupness" of such units, because their outer boundaries are highly fluid and their political decision making may be so muddled that no rational or coherent agency can be said to exist at the group level. For this reason, the cohesion of ethnic groups should be seen as a variable, at least in principle. In most cases, however, there are still good reasons to expect ethnic groups to be relatively cohesive and sufficiently stable to warrant conflict analysis of the type we propose. Ultimately, if our assumption of groups as units of analy-

23. For example, Shain and Barth 2003.

24. Collier and Hoeffler 2004.

25. Salehyan 2009.

26. Olson 1965.

27. See Brubaker 2004; and Kalyvas 2008. 
sis turns out to be deeply flawed, it should be impossible to find any clear empirical results based on ethnic groups as units of analysis.

Since demographic group size is relatively easy to measure, and tends to be exogenous to conflict except under extreme cases of ethnic cleansing, we rely on this dimension to reflect power in our theory. Although there are instances where the participants of conflict processes constitute tiny fractions of the group's population, such as ruthless warlords and armed bands, we expect the size of the group to be relevant to conflict onset in most cases, both in terms of potential resources and overall support or legitimacy as a share of a country's population.

Our main task, then, is to study the probability of violence within the primary dyad and to what extent this conflict process involves the TEK group through the secondary dyad. Assuming that a nationality conflict breaks out between the incumbent group(s) and the challenger, we derive the conditions of conflict as a function of the conditions within the primary and secondary dyads.

\section{Analyzing the Conditions of Conflict Within the Primary Dyad}

At least since the French Revolution, state sovereignty, and political legitimacy more widely, have been defined through the popular will. Wherever alien rule applies, leaders of the excluded groups are likely to harbor grievances against the incumbent state-controlling elites. ${ }^{28}$ Under specific conditions, these tensions increase the probability that the disadvantaged and excluded groups will resort to violence. ${ }^{29}$ Most obviously, the more pronounced the frustrations felt by the group in question, the more likely armed resistance becomes, especially where the path to peaceful change is blocked.

However, beyond popular grievances and demand for justice, the likelihood of violent conflict could also be influenced by the power balance within the primary dyad. After all, mere frustration does not suffice to challenge the state's power; violent change requires resources and organization in addition to motive. ${ }^{30}$ While Olson's classical theory of collective action postulates a negative relationship between group size and coordinated action at the group level because of the erosion of solidarity in large groups, other authors adopt a less radically individualist perspective by stressing how cognitive, ${ }^{31}$ emotional, ${ }^{32}$ and organizational mechanisms ${ }^{33}$ allow group leaders to tap resources in proportion to the size of the group in question.

28. Gellner 1983, 1.

29. See Goodwin 1997; Gurr 2000; Petersen 2002; and Cederman, Wimmer, and Min 2010.

30. Tilly 1978 .

31. Goldstone 2001.

32. Emirbayer and Goldberg 2005.

33. See Tilly 1978; and Gould 1991. 
We postulate a positive, monotonic relationship between group size and conflict for reasons relating to both opportunities and motivations. ${ }^{34}$ Assuming at least minimal cohesion, other things being equal, then groups with larger populations should be able to mobilize more resources to challenge the government's power, in terms of potential fighters and other types of material support.

We also expect demographic scope to be correlated with motivations to the extent that larger groups can claim more legitimacy within a political system, both in terms of actual votes in democracies or potential influence in authoritarian systems. In the modern, nationalist era, minority rule should be especially problematic. Wherever majorities — or at least large segments of the population - are deprived of political power, fundamental principles of democracy and national self-determination are by definition violated. Focusing on the relative size of the challenger group compared to the size of the incumbent groups, we propose our first hypothesis:

H1. The probability of conflict increases with the relative size of the challenger group in the primary dyad.

\section{Analyzing the Conditions of Conflict Within the Secondary Dyad}

Before discussing the different ways that the TEK group's size can affect the propensity of political violence, we consider a categorical effect. Such a formulation would be compatible with a strictly essentialist interpretation of ethnic kin that is unrelated to power relationships. As a reflection of strong ethnic solidarity, all TEK groups should be highly motivated to intervene. According to this approach, such groups are motivated by "reasons of affinity and sentiment rather than ... power or more hard-headed cost-benefit analyses." ${ }^{35}$ Based on this essentialist logic, we derive the following hypothesis:

\section{H2. The probability of conflict increases in the presence of a TEK group.}

We expect this hypothesis to be false. Although clearly emotionally loaded, ethnic politics is as much about power and politics as it is about ethnic solidarity:

Disputes over the allocation of scarce resources, competing visions of foreign policy directions, domestic political contests, and other prosaic features of political life frequently trump any putative duty that political elites might feel toward individuals who share their language or culture beyond their own frontiers. ${ }^{36}$

Whether orchestrated by state-owning or state-seeking ethnic kin, interventions in transborder conflicts are a risky business that can have massively negative conse-

34. For a justification of these assumptions, see Cederman, Buhaug, and Rød 2009.

35. See Holsti 1996, 127; and Connor 1994.

36. King and Melvin 1999/2000, 109. 
quences for the TEK group in question. ${ }^{37}$ Indeed, it is not surprising that quantitative studies have generally failed to find support for the simple hypothesis that the presence of a TEK group by itself influences conflict.

An alternative account takes power politics more seriously by letting the probability of conflict increase with the relative demographic weight of the TEK group compared to the incumbent. The larger the group, the more confident it will be that its intervention will contribute to the successful challenge of the government in the primary dyad without exposing it to inordinate risks. Similarly, powerful secondary dyads encourage groups in the primary dyad to radicalize and articulate larger demands, which can lead to violence. ${ }^{38}$ This logic runs parallel to that of $\mathrm{H} 1$ in the primary dyad by using relative demographic weight as a rough measure of the dyadic power balance:

\section{H3. The probability of conflict increases with the relative size of the TEK group in the secondary dyad.}

There are few examples of empirical studies measuring power relations in the secondary dyad and those that do typically find no proportional effect. For example, in their quantitative investigation of irredentism, Saideman and Ayres do not detect any influence of relative group size, which is also in line with Cetinyan's findings. ${ }^{39}$ Nonetheless, we include this hypothesis and test it using our new data resource.

But there are also important theoretical reasons to discount this hypothesis. H3's monotonic effect of TEK group size fails to account for the puzzle of the Russian near abroad, because it overlooks the strategic nature of the secondary dyad. As the size of the TEK group increases, the challenger in the primary dyad will have access to more resources, but the incumbent regime should also take this into account when bargaining with the group. We have postulated a linear effect of group size on conflict in the primary dyad, but there are good reasons to believe that such a relationship needs to be amended when it comes to the influence of the secondary dyad. Why should large, powerful TEK groups be able to "protect" their kin, but large groups in the primary dyad be more associated with conflict? Deviating somewhat from Van Houten's emphasis on commitment problems, we propose two causal mechanisms that generate the same relationship between the size and conflict variables.

First, large challengers in the primary dyad are relatively unlikely to extract bargaining concessions by threatening ruling minorities. Majority groups challenging minority incumbents will remain excluded from state power unless there are exceptional circumstances that make small ruling coalitions unstable. Some small

37. Horowitz 1985.

38. Jenne 2007.

39. See Saideman and Ayres 2000; and Cetinyan 2002. 
ruling coalitions-such as the white apartheid government in South Africaestablished their dominance through successful coercion, and managed to cling to power for decades. Oppressive incumbents are unlikely to compromise with challengers because they fear that concessions will threaten their long-term survival and the benefits of rule. Going down the reform path may lead to the dissolution of the regime at best, and exile, imprisonment, or death at worst. Thus, elites defending minority rule will be inclined to rely heavily on coercion to stifle challenges to their supremacy. ${ }^{40}$

However, such an uncompromising attitude may be much less viable if overwhelming external groups get involved. While incumbents have greater means to maintain control domestically, transnational actors are inherently more difficult to police and coerce since they can mobilize resources beyond the shadow of repression. ${ }^{41}$ Because of the potential threat posed by such interventions, we would expect incumbent regimes to be mindful of ethnic opposition groups' respective "homelands." In other words, large domestic challengers-while potentially threateningcan be successfully controlled by the state's coercive apparatus, but large external challengers are much more difficult to deal with.

This type of caution should increase with the TEK group's size relative to the incumbent group. Stated differently, the incumbent's willingness to risk violent conflict should be a decreasing function of the TEK group's size. Yet since the probability of conflict results from both opportunity and willingness, the combination (that is, multiplication) of external resources and external treats produces a curvilinear effect. For small TEK groups, the conflict propensity would be close to 0 since these groups would make little difference even if they intervene. Where the TEK groups are relatively large, however, states will be more constrained in their behavior because of the deterrent effect of a possible intervention.

Drawing on bargaining theory, there is a second reason to expect the midrange of TEK sizes to be more conflictual. Originally applied by Blainey to interstate relations, this argument hinges critically on uncertainty and strategic incentives to misrepresent one's true strength. ${ }^{42}$ According to this reasoning, conflicts are especially likely to break out where the power balance is roughly even. ${ }^{43}$ Rough parity makes it difficult for the parties to assess who would prevail in case of combat, and so attempts to misrepresent gain significance. ${ }^{44}$ Conflict may then occur as the result of information problems leading to bargaining failure. ${ }^{45}$ While this reasoning has generally not been extended to civil wars, which are typically thought to be caused by commitment problems ${ }^{46}$ there are clear reasons to believe that

\author{
40. Heger and Salehyan 2007. \\ 41. Salehyan 2009. \\ 42. Blainey 1973. \\ 43. Reiter 2003. \\ 44. See Geller 1993; Lemke and Werner 1996; and Wagner 2000. \\ 45. Fearon 1995. \\ 46. For example, Fearon 1995 and 1998.
}


uncertainty could be a cause of conflict in such settings. For example, Walter points to obvious sources of uncertainty, such as the sources of rebel financing and governmental resolve, to which one might add the extent of popular mobilization on either side. ${ }^{47}$

Yet, the lack of information should be even more pronounced regarding the possible involvement of TEK groups. Transnational interactions will tend to be much less transparent than domestic politics. This fundamental information asymmetry is especially severe for the incumbent, because its intelligence services are likely to encounter much more resistance in their attempts to gather information about the resources and intentions of foreign groups. ${ }^{48}$ To some degree, the situation resembles the difficulties surrounding extended deterrence in international relations, which is especially challenging to handle. Primarily the challenge derives from the uncertainty and lacking credibility surrounding third parties' propensity to intervene in defense of proxy states. ${ }^{49}$ Thus, both in terms of estimating the capability balance in the TEK group's favor and its willingness to intervene, considerable uncertainties will be present, especially when approaching power parity. Furthermore, these uncertainties should dwarf the corresponding sources of ambiguity in domestic politics.

We thus present our main hypothesis regarding the functional form of the TEK effect:

H4. The probability of conflict follows an inverted $U$-shape for the relative size of the TEK group in the secondary dyad.

So far, our hypotheses have said nothing about the influence of TEK links on conflict compared to situations that feature no kin at all. Whether the TEK group is included in, or excluded from, executive power in their own state exerts a mediating effect. The most straightforward argument focuses on the superior power of state-controlling TEK. Other things being equal, we would expect TEK groups that control a state to be more powerful. Yet as we have argued, the relative power balance in the secondary dyad should constrain conflict as TEK groups become more threatening. While we focused on power-as-population earlier, control of a state and its military apparatus should augment power even further. Thus, while ethnic Russians and ethnic Chinese are numerically large in global terms, they are even stronger than their size alone would suggest because they control powerful states. Marginalized TEK groups, on the other hand, may be willing and able to mobilize resources for their kin in their primary state. Yet, there will be considerable uncertainty over the resources and support that they can garner because their capabilities are unknown and resource pools are insecure. TEKs that control states

47. Walter 2009.

48. Salehyan 2009, 48.

49. For example, Huth 1988. 
usually operate through official diplomatic channels and have known resource streams and capabilities, which bolster credible threats and reduce bargaining uncertainty.

In addition, we must consider the TEK group's willingness to intervene. Incumbent groups have much more to lose than stateless groups, especially in the case of multiethnic polities that could be seriously destabilized by actions that undermine the sanctity of borders. ${ }^{50}$ International norms of territorial integrity applying to states, rather than to nonstate actors, should also restrain incumbent groups from interfering in the internal affairs of neighboring states. ${ }^{51}$ In contrast, TEK groups without access to power, such as the Kurds in Turkey, are less bound by such rules and are generally more likely to have experienced military action as a consequence of their marginal position.

In short, TEK groups that control a state can "talk softly and carry a big stick." They are more able to intervene given their control over military forces and these credible threats should be reflected in bargaining in the primary dyad. They may be more reserved in their use of force, given international norms against war, but can still bring the power of the state to bear in diplomatic relations. Marginalized TEK groups on the other hand, do not face similar constraints. Support for their kin may be uncertain and difficult to mobilize since they do not have the same military capabilities. For these reasons, large included TEK groups tend to deter conflict, while excluded TEK groups can foster bargaining uncertainty and promote conflict. Thus, we state our final hypothesis:

H5. The conflict-dampening effect occurs for relatively large TEK groups that are included, and not for those that are excluded.

\section{Data}

Assessing our hypotheses empirically requires suitable data on ethnic groups and their transnational connections in a wide and unbiased sample. Thus, we extend the EPR data set to encompass transborder links. The coding of EPR relies extensively on expert input, both through an online survey and workshops. ${ }^{52}$ In its current version, EPR-ETH, the data set contains information about politically relevant ethnic groups around the world from 1946 through $2009 . .^{53}$ Political relevance is defined by including groups that are active in national politics and/or directly discriminated against by the government.

50. See Horowitz 1985; and Cederman, Girardin, and Gleditsch 2009.

51. Zacher 2001.

52. Cederman, Wimmer, and Min 2010.

53. Ethnic Power Relations Data Set (EPR-ETH), Version 2.0, available at $\langle$ http://www.icr.ethz.ch/ data), accessed 27 October 2012. 
In agreement with constructivist principles, the ethnic identities are allowed to vary over time, such that the political relevance or the main level of political identification may move from one level to another. For each group and time period, we provide the demographic weight and access to national executive power. The data set divides power status into three main categories depending on whether the group in question (1) controls power alone, (2) shares power, or (3) is excluded from power. Whereas groups that fall into the two first categories are included, those that belong to the last category are excluded.

The EPR classification offers subcategories for each of the three main status categories:

1. Included groups that rule alone can be either in monopoly or be dominant depending on whether the control is total or allows for "token" representation.

2. Included groups that share power play either a senior or junior role measured by their absolute influence over the cabinet.

3. Excluded groups are either powerless if their access to power is blocked, discriminated if the exclusion is systematic and targeted, and autonomous or separatist, if they have been granted, or unilaterally secured, regional autonomy respectively. ${ }^{54}$

Our data set offers an important extension covering transnational groups between ethnically related kin groups. Since the coding of EPR groups is country specific, there is no automatic way of identifying such connections. We therefore decided to code TEK links based on nominal identification by matching group names including the possibility of synonyms for groups with shared languages. Thus, for example, Swiss Italians are linked to the Italians through the TEK group for all Italians. There is, of course, no guarantee that matching names will yield politically relevant bonds, and it is far from obvious whether Swiss Italians automatically will identify with "Italian Italians." However, this method is less afflicted by bias than attempts to code constructivist interpretations based on partial information. ${ }^{55}$

The coders were asked to identify all ethnic groups that appear in more than one country and to give them a special TEK code that differs from the countryspecific group identifiers. Groups that appear in only one country were not given any TEK code. EPR also features "umbrella groups" composed of several ethnic subgroups; for example, in Mali the umbrella group "blacks" includes ethnic Mande, Peul, Voltaic, and others. In these cases, the composite group can be associated with more than one TEK code, with three as the maximum number of links allowed in the data set. Finally, before entering the analysis, TEK connections featuring

54. In these cases, the autonomous group has no access to national executive power. Autonomous groups that are represented at the national level are coded as included.

55. See the online appendix for a full listing of all TEK groups. 
groups from noncontiguous countries were removed from the data set in agreement with the reasoning presented earlier.

\section{Variables}

Throughout this research note, we rely on a dependent variable that is based on a group-level coding of the Uppsala Conflict Data Program's Armed Conflict Data Set. ${ }^{56}$ The resulting coding ensures that each conflict onset is mapped to the corresponding EPR group provided that the rebel organization expresses an aim to support the ethnic group and members of the group in question participate in combat. ${ }^{57}$ The onset variable is coded 1 for a group-year during which a conflict started, and 0 otherwise. We exclude observations with ongoing conflict.

Assuming that the group's population is $G$, the TEK group's population $K{ }^{58}$ and the population of the incumbent $I,{ }^{59}$ we operationalize the main independent variables as follows:

- Relative group size $g \in(0,1)$ in the primary dyad is defined as $G /(G+I)$ if the group is excluded and as $G / I$ if the group is included (since the group left the governing coalition, which is now of size $I-G)$.

- Relative TEK size $k \in[0,1)$ in the secondary dyad is defined as $K /(K+I)$.

- Relative size for TEK groups that are state controlling and stateless, $k_{\mathrm{INCL}}$ and $k_{\mathrm{EXCL}}$ respectively, are computed based on TEK group populations from either group category.

- We also employ a TEK dummy variable, which is coded 1 if the group has at least one TEK group, and 0 otherwise.

We control for a number of group-level properties, including:

- Dummy variables for the EPR categories: JUNIOR PARTNER, POWERLESS, DISCRIMINATED, REGIONAL AUTONOMY, and SEPARATIST AUTONOMY (using SENIOR PARTNER in power sharing as the reference category, while dropping all cases pertaining to MONOPOLY and DOMINANT status since groups cannot challenge themselves).

- Dummy variable Downgraded, which indicates if the group suffered a loss of EPR status during the last two years.

56. Gleditsch et al. 2002.

57. Wucherpfennig et al. 2012.

58. Note that there may be more than one TEK group. In such cases, $K$ is the sum of the population of segments in all neighboring countries.

59. Note that the incumbent group can consist of several groups. In this case, $I$ is the sum of these groups' population. 
- Count variable PREvious CONFLICTS which shows the number of conflicts the group has experienced since 1946 or the country's independence.

Finally, we introduce a number of variables to control for country-level properties:

- Dummy variable ongoing CONFLict, which indicates if there was an ongoing conflict involving any other group in the country during the preceding year.

- Logged gross domestic product (GDP) PER CAPITA of the country, lagged.

- Logged POPUlation SIZE of the country, lagged.

- Number of years since last conflict, as a nonlinear function, based on natural splines with three knots. ${ }^{60}$

\section{Results}

The sample encompasses all politically relevant EPR groups from 1946 through 2009, which amounts to 28,302 group years of which 203 include conflict onsets (except those groups that control the government through monopoly or dominance). Relying on robust country-clustered standard errors, we conduct all analysis with logit models using the onset of ethno-nationalist conflict at the group level as the dependent variable.

Table 1 introduces five models that test successively the hypotheses $\mathrm{H} 1$ through H5. Starting with an evaluation of H1, Model 1 confirms that larger relative group sizes in the primary dyad increase the probability of conflict. ${ }^{61}$ The control variables behave as anticipated. The group's power access is negatively related to conflict. ${ }^{62}$ Downgraded groups and those with a history of conflict are more likely to experience violence. At the country level, GDP per capita has a negative and significant effect, but the population variable fails to reach significance.

The remaining models assess the conditions within the secondary dyad. As a first step, Model 2 introduces a dummy variable indicating whether the group has TEK. Since the effect is indistinguishable from 0 , we reject $\mathrm{H} 2$ in keeping with our theoretical expectations. The introduction of the TEK dummy variable does little to affect the other coefficients. Focusing on H3, Model 3 evaluates whether the probability of conflict increases monotonically with the relative size of the TEK group. We retain the TEK dummy, which now serves as an intercept for the linear effect for groups without TEK, where the size is set to 0. Again, the estimate of the size effect is far from significant, although this time positive. In agreement with our theoretical anticipation, we reject $\mathrm{H} 3$ as well.

60. Beck, Katz, and Tucker 1998.

61. Cederman, Buhaug, and Rød 2009.

62. This result confirms Cederman, Wimmer, and Min 2010. 
TABLE 1. Main regression results

\begin{tabular}{|c|c|c|c|c|c|}
\hline & $\begin{array}{l}\text { Model } 1 \\
\text { onset }\end{array}$ & $\begin{array}{c}\text { Model } 2 \\
\text { onset }\end{array}$ & $\begin{array}{c}\text { Model } 3 \\
\text { onset }\end{array}$ & $\begin{array}{c}\text { Model } 4 \\
\text { onset }\end{array}$ & $\begin{array}{l}\text { Model } 5 \\
\text { onset }\end{array}$ \\
\hline RELATIVE GROUP SIZE & $\begin{array}{l}1.3885^{* *} \\
(0.3145)\end{array}$ & $\begin{array}{l}1.3807 * * \\
(0.3131)\end{array}$ & $\begin{array}{l}1.2713 * * \\
(0.3347)\end{array}$ & $\begin{array}{l}1.2622 * * \\
(0.3404)\end{array}$ & $\begin{array}{l}1.1783^{* *} \\
(0.3659)\end{array}$ \\
\hline TEK GROUP & & $\begin{array}{c}0.1009 \\
(0.1927)\end{array}$ & $\begin{array}{c}-0.0179 \\
(0.2092)\end{array}$ & $\begin{array}{c}-0.4115 \\
(0.2440)\end{array}$ & \\
\hline RELATIVE TEK SIZE & & & $\begin{array}{c}0.3441 \\
(0.3306)\end{array}$ & $\begin{array}{l}4.2382 * * \\
(1.3420)\end{array}$ & \\
\hline RELATIVE TEK SIZE, $s q$. & & & & $\begin{array}{c}-4.2058 * * \\
(1.3620)\end{array}$ & \\
\hline EXCLUDED TEK GROUP & & & & & $\begin{array}{c}-0.1967 \\
(0.2237)\end{array}$ \\
\hline RELATIVE TEK SIZE (EXCL.) & & & & & $\begin{array}{c}3.3767 * \\
(1.6882)\end{array}$ \\
\hline RELATIVE TEK SIZE (EXCL.), $s q$. & & & & & $\begin{array}{c}-2.6340 \\
(1.9853)\end{array}$ \\
\hline INCLUDED TEK GROUP & & & & & $\begin{array}{c}-0.3549 \\
(0.2852)\end{array}$ \\
\hline RELATIVE TEK SIZE (INCL.) & & & & & $\begin{array}{l}4.5133^{* *} \\
(1.6719)\end{array}$ \\
\hline RELATIVE TEK SIZE (INCL.), $s q$. & & & & & $\begin{array}{c}-5.1434 * * \\
(1.6867)\end{array}$ \\
\hline JUNIOR PARTNER & $\begin{array}{c}0.8392 \\
(0.5210)\end{array}$ & $\begin{array}{c}0.8415 \\
(0.5207)\end{array}$ & $\begin{array}{c}0.7939 \\
(0.5295)\end{array}$ & $\begin{array}{c}0.7823 \\
(0.5248)\end{array}$ & $\begin{array}{c}0.7781 \\
(0.5323)\end{array}$ \\
\hline REGIONAL AUTONOMY & $\begin{array}{c}1.1844 * \\
(0.5758)\end{array}$ & $\begin{array}{l}1.2021 * \\
(0.5741)\end{array}$ & $\begin{array}{c}1.1249 \\
(0.5840)\end{array}$ & $\begin{array}{l}1.1647 * \\
(0.5811)\end{array}$ & $\begin{array}{c}1.1097 \\
(0.5852)\end{array}$ \\
\hline POWERLESS & $\begin{array}{l}1.4248 * * \\
(0.5294)\end{array}$ & $\begin{array}{l}1.4237 * * \\
(0.5309)\end{array}$ & $\begin{array}{l}1.3527 * \\
(0.5430)\end{array}$ & $\begin{array}{l}1.3675^{*} \\
(0.5396)\end{array}$ & $\begin{array}{l}1.3039 * \\
(0.5458)\end{array}$ \\
\hline DISCRIMINATED & $\begin{array}{l}2.0008^{* *} \\
(0.5048)\end{array}$ & $\begin{array}{l}1.9905 * * \\
(0.5075)\end{array}$ & $\begin{array}{l}1.9315^{* *} \\
(0.5194)\end{array}$ & $\begin{array}{l}1.9273 * * \\
(0.5162)\end{array}$ & $\begin{array}{l}1.8952 * * \\
(0.5177)\end{array}$ \\
\hline SEPARATIST & $\begin{array}{l}3.2109 * * \\
(0.6592)\end{array}$ & $\begin{array}{l}3.2137 * * \\
(0.6609)\end{array}$ & $\begin{array}{l}3.1275^{* *} \\
(0.6818)\end{array}$ & $\begin{array}{l}3.2512 * * \\
(0.6625)\end{array}$ & $\begin{array}{l}3.2108 * * \\
(0.6660)\end{array}$ \\
\hline DOWNGRADED & $\begin{array}{l}1.5762 * * \\
(0.2935)\end{array}$ & $\begin{array}{l}1.5768 * * \\
(0.2942)\end{array}$ & $\begin{array}{l}1.5756^{* * *} \\
(0.2950)\end{array}$ & $\begin{array}{l}1.5585 * * \\
(0.2922)\end{array}$ & $\begin{array}{l}1.5537 * * \\
(0.2898)\end{array}$ \\
\hline PREVIOUS CONFLICTS & $\begin{array}{l}0.5571 * * \\
(0.0972)\end{array}$ & $\begin{array}{l}0.5481 * * \\
(0.0968)\end{array}$ & $\begin{array}{l}0.5469 * * \\
(0.0959)\end{array}$ & $\begin{array}{l}0.5173 * * \\
(0.0963)\end{array}$ & $\begin{array}{l}0.5070^{* *} \\
(0.0933)\end{array}$ \\
\hline ONGOING CONFLICT, lag & $\begin{array}{c}0.3876 \\
(0.2882)\end{array}$ & $\begin{array}{c}0.3903 \\
(0.2856)\end{array}$ & $\begin{array}{c}0.3960 \\
(0.2866)\end{array}$ & $\begin{array}{c}0.4421 \\
(0.2864)\end{array}$ & $\begin{array}{c}0.4634 \\
(0.2856)\end{array}$ \\
\hline GDP/CAPITA, lag, $\log$ & $\begin{array}{c}-0.1672^{*} \\
(0.0727)\end{array}$ & $\begin{array}{c}-0.1707^{*} \\
(0.0722)\end{array}$ & $\begin{array}{c}-0.1674 * \\
(0.0726)\end{array}$ & $\begin{array}{c}-0.1777^{*} \\
(0.0728)\end{array}$ & $\begin{array}{c}-0.1918 * \\
(0.0756)\end{array}$ \\
\hline POPULATION SIZE, lag, $\log$ & $\begin{array}{c}0.0827 \\
(0.0895)\end{array}$ & $\begin{array}{c}0.0866 \\
(0.0889)\end{array}$ & $\begin{array}{c}0.0989 \\
(0.0937)\end{array}$ & $\begin{array}{c}0.1198 \\
(0.0957)\end{array}$ & $\begin{array}{c}0.1386 \\
(0.0969)\end{array}$ \\
\hline CONSTANT & $\begin{array}{c}-5.7704 * * \\
(1.0971)\end{array}$ & $\begin{array}{c}-5.8275^{* *} \\
(1.0901)\end{array}$ & $\begin{array}{c}-5.9053 * * \\
(1.1246)\end{array}$ & $\begin{array}{c}-6.1146 * * \\
(1.1326)\end{array}$ & $\begin{array}{c}-6.2274 * * \\
(1.1281)\end{array}$ \\
\hline Observations & 28302 & 28302 & 28298 & 28298 & 28298 \\
\hline
\end{tabular}

Notes: Robust standard errors are in parentheses; estimates for peace-year correction are not shown. $* * p<.01 ; * p<.05$.

Next, we test the postulated inverted U-shaped curvilinear relationship between TEK size and conflict. Since the indicator for the demographic balance ranges from 0 to 1 , both terms should be of roughly equal magnitude and the quadratic term should be negative if the hypothesis is supported. In support of H4, the estimates of Model 4 reveal that while the monotonic effect of relative group size in the primary dyad remains strong, the relative size of the TEK group influences 
conflict propensity in an inverted U-shaped fashion. Encouragingly, both the linear and square terms are strongly significant, with the former being positive and the latter negative. Using 90 percent confidence intervals, Figure 2 plots the predicted probability of conflict as a function of relative TEK size, indicating that if the other variables are held at their means, conflict propensity increases from around 0.003 to as much as 0.008 per group and year if the relative TEK size shifts from 0 to parity. Illustrating the distribution of the observations, the rug plot along the $x$-axis of Figure 2 demonstrates considerable variation in the observed relative size of TEK groups.

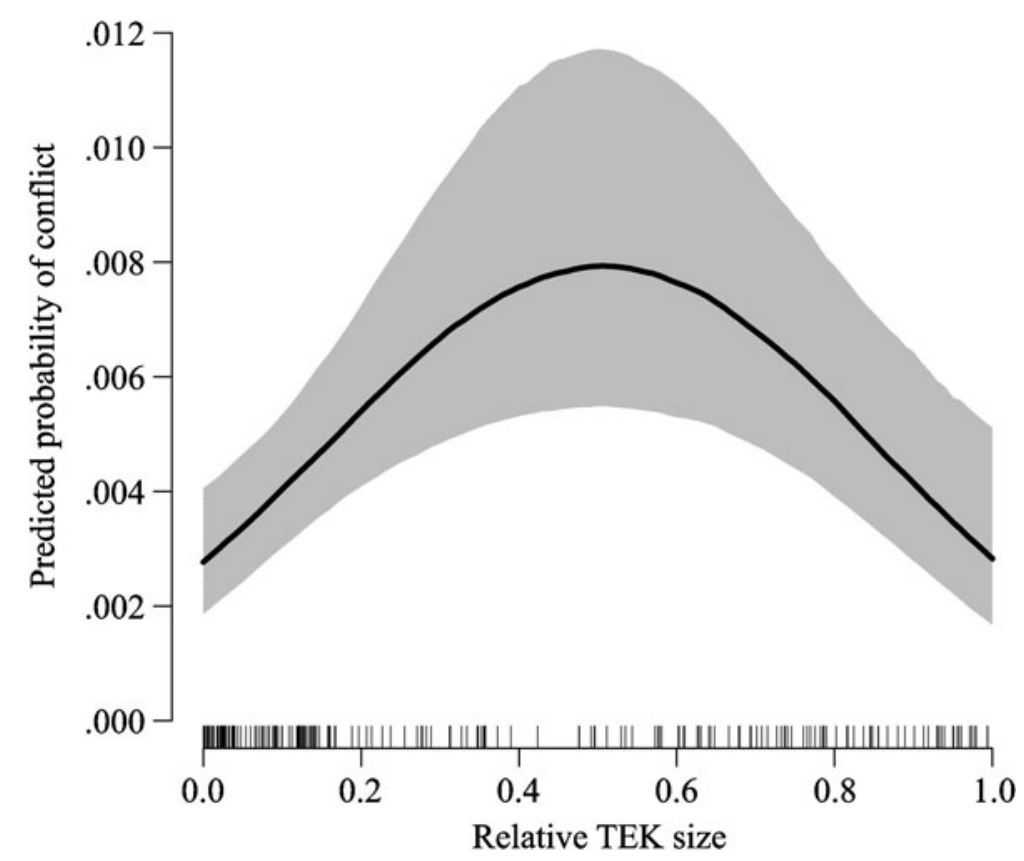

FIGURE 2. The probability of conflict as a function of relative TEK size

Our analysis continues with an evaluation of H5, which considers the separate effect of different types of TEK groups compared to the non-TEK baseline. The results of Model 5 suggest that both included and excluded TEK groups produce a curvilinear effect on conflict onset. However, it is difficult to compare the net influence of both these variables based on the coefficients themselves. We therefore refer to Figure 3, which displays the respective marginal TEK effects in two separate panels, with the left indicating included TEK groups and the right corresponding to excluded groups. The figure thus depicts the first differences in predicted probabilities for given levels of relative TEK size and status compared to groups 
without TEK. It immediately becomes clear that the effect differs significantly between the two types of TEK groups. In support of H5, the graphs show that for comparable TEK sizes, the conflict propensity is considerably higher for excluded TEK groups than for the included ones. In fact, the conflict-restraining effect can be observed for state-controlling TEK groups only. For very large relative group sizes, the effect appears to be significant since the error bands do not intersect 0 in that range. By contrast, the marginal effect of excluded TEKs is generally positive and statistically significant for the intermediate size range, but becomes indistinguishable from the corresponding non-TEK situation for extreme values of the size spectrum. However, despite a falling tendency for large groups, the net effect never becomes conflict dampening. Echoing the findings of Saideman and Ayres, ${ }^{63}$ we conclude that irredentism may be much less important as a trigger of civil wars than often expected, although we cannot exclude the possibility that other types of violence, such as interstate disputes and wars, could be triggered by included TEK groups. Indeed, our results indicate that the conflict-dampening influence appears to be limited to included TEK groups, in line with Van Houten's account of the relatively peaceful Russian diaspora. ${ }^{64}$
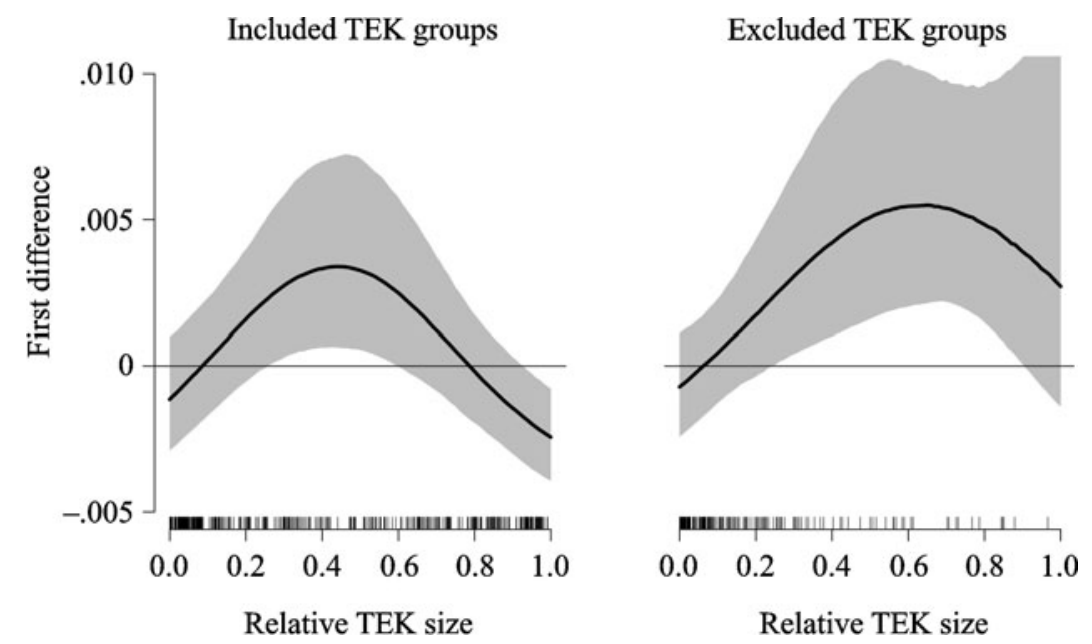

FIGURE 3. Change in conflict probability varying with size of included and excluded TEK groups

In order to increase our confidence in our findings, we conducted a number of sensitivity tests, presented in the online appendix. We find that the results hold for

64. Van Houten 1998. 
different parts of the world and are robust to several potentially confounding factors. ${ }^{65}$

\section{Conclusion}

Thanks to improved data and analysis, this study has been able to provide considerable empirical support for conjectures that have so far been postulated only theoretically, or shown to hold for selected cases. In agreement with earlier studies, we show that as the relative strength of ethnic kin groups increases, the risk of internal conflict also grows, but only up to a certain point. After this point, further increases in the ethnic kin's demographic weight have a dampening impact on conflict propensity. Whereas the former part of the relationship is quite straightforward, the latter part is much less obvious, but nevertheless of great importance. Indeed, it is this conflict-reducing influence of large "homelands" that enables us to resolve our main puzzle relating to the relative peacefulness of the Russian diaspora. It is not surprising that the calming influence is limited to included, rather than excluded, TEK groups, such as the Russians in Russia. More generally, our study offers a powerful answer to those who have played up the risks of irredentism. Our counterintuitive finding makes sense as soon as one realizes that large, state-owning TEK groups are less likely to resort to risky border-crossing adventures, and their presence puts pressure on incumbent states to treat their minorities with foreign kin in a more considerate way than would otherwise have been the case.

These findings do not imply that transnational politics is always more peaceful than domestic dynamics. In contrast to the conflict-inhibiting influence of large state-controlling TEK groups, we find exactly the opposite effect for intermediatesize kin groups. Indeed, the probability of conflict hinges critically on the power status of the TEK group. Stateless communities, such as the Kurds (outside Iraq), exhibit a much higher conflict potential compared to the within-country baseline. Thus, the pernicious effect of political exclusion has a tendency to spill over state borders. Since marginalized communities have little to lose at home, they also are more willing to upset the status quo abroad in the name of ethnic solidarity and commonly felt grievances.

Although our main task has been to test empirically the curvilinear theoretical conjecture and to evaluate TEK groups' net impact on conflict, our empirical analysis has important additional theoretical implications. For one, our analysis stresses the importance of considering nonlinear specifications rather than merely postu-

65. See the online appendix at www.journals.cambridge.org/ino2013005. In particular, there is evidence that actual or prospective membership in the European Union influences the likelihood of irredentist conflict when we included a dummy variable for such countries in our models. However, this modification does not change our main results. 
lating monotonic effects. But our study also has general relevance for substantive theory building. By introducing the conceptual distinction between primary and secondary dyads, we are able to unpack the "ethnic triad" originally introduced by Weiner, ${ }^{66}$ while at the same time going beyond analysis that studies the influence of ethnic kin as a dichotomous feature. ${ }^{67}$ Indeed, our results show that the power balance in the primary and secondary dyads affects the risk of civil war in potentially quite different ways. The central curvilinear finding for the secondary dyad dovetails nicely with international relations theory, especially the strands highlighting the importance of uncertainty and deterrence. Although several studies using conventional balance-of-power theory have shown that the risk of conflict is the highest at power parity, we do not find strong evidence of such an inverted U-shape relationship in the primary dyad. It seems intuitive that the secondary dyad involves strategic considerations that have more to do with interstate relations than with domestic politics, especially since transnational relations can be expected to feature more uncertainty than domestic dyads. Yet more research is needed to clarify the causal mechanisms operating in the primary and secondary dyads, as well as possible interdependencies between them.

\section{References}

Beck, Nathaniel, Jonathan N. Katz, and Richard M. Tucker. 1998. Taking Time Seriously: Time-SeriesCross-Section Analysis with a Binary Dependent Variable. American Journal of Political Science 42 (4):1260-88.

Blainey, Geoffrey. 1973. The Causes of War. New York: Free Press.

Brubaker, Rogers. 1996. Nationalism Reframed: Nationhood and the National Question in the New Europe. Cambridge: Cambridge University Press.

- 2004. Ethnicity Without Groups. Cambridge, Mass.: Harvard University Press.

Bruk, Solomon I., and V.S. Apenchenko, eds. 1964. Atlas Narodov Mira (Atlas of the Peoples of the World). Moscow: Glavnoe Upravlenie Geodezii I Kartografi.

Cederman, Lars-Erik, Halvard Buhaug, and Jan Ketil Rød. 2009. Ethno-Nationalist Dyads and Civil War: A GIS-Based Analysis. Journal of Conflict Resolution 53 (4):496-525.

Cederman, Lars-Erik, Luc Girardin, and Kristian Skrede Gleditsch. 2009. Ethnonationalist Triads: Assessing the Influence of Kin Groups on Civil Wars. World Politics 61 (3):403-37.

Cederman, Lars-Erik, Andreas Wimmer, and Brian Min. 2010. Why Do Ethnic Groups Rebel? New Data and Analysis. World Politics 62 (1):87-119.

Cetinyan, Rupen. 2002. Ethnic Bargaining in the Shadow of Third-Party Intervention. International Organization 56 (3):645-77.

Chazan, Naomi, ed. 1991. Irredentism and International Politics. Boulder, Colo.: Lynne Rienner.

Collier, Paul, and Anke Hoeffler. 2004. Greed and Grievance in Civil War. Oxford Economic Papers 56 (4):563-95.

Connor, Walker. 1994. Ethnonationalism: The Quest for Understanding. Princeton, N.J.: Princeton University Press.

66. Weiner 1971.

67. For example, Cederman, Girardin, and Gleditsch 2009. 
Davis, David R., and Will H. Moore. 1997. Ethnicity Matters: Transnational Ethnic Alliances and Foreign Policy Behavior. International Studies Quarterly 41 (1):171-84.

Emirbayer, Mustafa, and Chad Alan Goldberg. 2005. Pragmatism, Bourdieu, and Collective Emotions in Contentious Politics. Theory and Society 34 (5-6):469-518.

Fearon, James D. 1995. Rationalist Explanations for War. International Organization 49 (3):379-414.

- 1998. Commitment Problems and the Spread of Ethnic Conflict. In The International Spread of Ethnic Conflict: Fear, Diffusion, and Escalation, edited by David A. Lake and Donald Rothchild, 107-26. Princeton, N.J.: Princeton University Press.

Geller, Daniel S. 1993. Power Differentials and War in Rival Dyads. International Studies Quarterly 37 (2):173-93.

Gellner, Ernest. 1983. Nations and Nationalism. Ithaca, N.Y.: Cornell University Press.

Gleditsch, Kristian Skrede. 2007. Transnational Dimensions of Civil War. Journal of Peace Research 44 (3):293-309.

Gleditsch, Nils Petter, Peter Wallensteen, Mikael Eriksson, Margareta Sollenberg, and Håvard Strand. 2002. Armed Conflict 1946-2001: A New Dataset. Journal of Peace Research 39 (5):615-37.

Goldstone, Jack A. 2001. Toward a Fourth Generation of Revolutionary Theory. Annual Review of Political Science 4:139-87.

Goodwin, Jeff. 1997. State-Centered Approaches to Social Revolutions: Strengths and Limitations of a Theoretical Tradition. In Theorizing Revolutions, edited by John Foran, 9-35. London: Routledge.

Gould, Roger V. 1991. Multiple Networks and Mobilization in the Paris Commune, 1871. American Sociological Review 56 (6):716-29.

Gurr, Ted Robert. 2000. Peoples Versus States: Minorities at Risk in the New Century. Washington, D.C.: United States Institute of Peace Press.

Heger, Lindsay, and Idean Salehyan. 2007. Ruthless Rulers: Coalition Size and the Severity of Civil Conflict. International Studies Quarterly 51 (2):385-403.

Hegre, Håvard, Tanja Ellingsen, Scott Gates, and Nils Petter Gleditsch. 2001. Toward a Democratic Civil Peace? Democracy, Political Change, and Civil War, 1816-1992. American Political Science Review 95 (1):33-48.

Heraclides, Alexis. 1990. Secessionist Minorities and External Involvement. International Organization 44 (3):341-78.

Holsti, Kalevi J. 1996. The State, War, and the State of War. Cambridge: Cambridge University Press.

Horowitz, Donald L. 1985. Ethnic Groups in Conflict. Berkeley: University of California Press.

Huth, Paul K. 1988. Extended Deterrence and the Prevention of War. New Haven, Conn.: Yale University Press.

Jenne, Erin K. 2007. Ethnic Bargaining: The Paradox of Minority Empowerment. Ithaca, N.Y.: Cornell University Press.

Kalyvas, Stathis N. 2008. Ethnic Defection in Civil War. Comparative Political Studies 41 (8):1043-68.

King, Charles, and Neil J. Melvin. 1999/2000. Diaspora Politics: Ethnic Linkages, Foreign Policy, and Security in Eurasia. International Security 24 (3):108-38.

Lemke, Douglas, and Suzanne Werner. 1996. Power Parity, Commitment to Change, and War. International Studies Quarterly 40 (2):235-60.

Olson, Mancur. 1965. The Logic of Collective Action: Public Goods and the Theory of Groups. Cambridge, Mass.: Harvard University Press.

Petersen, Roger D. 2002. Understanding Ethnic Violence: Fear, Hatred, and Resentment in TwentiethCentury Eastern Europe. Cambridge: Cambridge University Press.

Reiter, Dan. 2003. Exploring the Bargaining Model of War. Perspectives on Politics 1 (1):27-43.

Saideman, Stephen M. 2001. The Ties That Divide: Ethnic Politics, Foreign Policy, and International Conflict. New York: Columbia University Press.

Saideman, Stephen M., and R. William Ayres. 2000. Determining the Causes of Irredentism: Logit Analyses of Minorities at Risk Data from the 1980s and 1990s. Journal of Politics 62 (4):1126-44.

. 2008. For Kin or Country: Xenophobia, Nationalism, and War. New York: Columbia University Press. 
Salehyan, Idean. 2009. Rebels Without Borders: Transnational Insurgencies in World Politics. Ithaca, N.Y.: Cornell University Press.

Salehyan, Idean, and Kristian Skrede Gleditsch. 2006. Refugees and the Spread of Civil War. International Organization 60 (2):335-66.

Sambanis, Nicholas. 2001. Do Ethnic and Nonethnic Civil Wars Have the Same Causes? A Theoretical and Empirical Inquiry (Part 1). Journal of Conflict Resolution 45 (3):259-82.

Shain, Yossi, and Aharon Barth. 2003. Diasporas and International Relations Theory. International Organization 57 (3):449-79.

Thyne, Clayton L. 2006. Cheap Signals with Costly Consequences: The Effect of Interstate Relations on Civil War. Journal of Conflict Resolution 50 (6):937-61.

Tilly, Charles. 1978. From Mobilization to Revolution. New York: Addison-Wesley.

Van Evera, Stephen. 1994. Hypotheses on Nationalism and War. International Security 18 (4):5-39.

Van Houten, Pieter. 1998. The Role of a Minority's Reference State in Ethnic Relations. Archives Européennes de Sociologie 39 (1):110-46.

Wagner, R. Harrison. 2000. Bargaining and War. American Journal of Political Science 44 (3):469-84.

Walter, Barbara F. 2009. Bargaining Failures and Civil War. Annual Review of Political Science 12:243-61.

Weidmann, Nils B., Jan Ketil Rød, and Lars-Erik Cederman. 2010. Representing Ethnic Groups in Space: A New Dataset. Journal of Peace Research 47 (4):491-99.

Weiner, Myron. 1971. The Macedonian Syndrome: An Historical Model of International Relations and Political Development. World Politics 23 (4):665-83.

Woodwell, Douglas. 2004. Unwelcome Neighbors: Shared Ethnicity and International Conflict During the Cold War. International Studies Quarterly 48 (1):197-223.

Wucherpfennig, Julian, Nils W. Metternich, Lars-Erik Cederman, and Kristian Skrede Gleditsch. 2012. Ethnicity, the State, and the Duration of Civil War. World Politics 64 (1):79-115.

Zacher, Mark W. 2001. The Territorial Integrity Norm: International Boundaries and the Use of Force. International Organization 55 (2):215-50. 